\title{
USA, Australia and China collaborate over Pacific Ocean
}

\section{San Francisco}

A RESEARCH programme deemed to be one of the biggest and most sophisticated studies ever assembled to probe the dynamics of storm systems and their influence on upper atmosphere chemistry has just been launched.

The world's highest, coldest thunderstorms, which billow into the stratosphere every January and February above the tropical Arafura Sea north of Australia and the neighbouring Indonesian archipelago, may be the key to a vexing meteorological problem: how gases move between the upper and lower atmosphere.

A US National Aeronautics and Space Administration (NASA) ER-2 jet at an altitude of $20 \mathrm{~km}$ will test a novel hypothesis proposed about five years ago that these tropical storms in this restricted portion of the globe throw large volumes of lower atmosphere to higher levels and simultaneously preserve the extraordinarily low humidity of the lower stratosphere. The aircraft test is part of a US\$10 million NASA project called Stratosphere-Troposphere Exchange Project (STEP). If the theory is supported, the warm seas northeast of Australia may contain the prime meteorological channel through which the bulk of atmospheric contaminants, including industrial discharges such as ozone-destroying fluorocarbon products, reach the stratosphere. Reginald Newell, professor of meteorology at Massachusetts Institute of Technology and an adviser to the programme, has called the area a "stratospheric fountain".

The single-engined ER-2, a research version of the US Air Force TR-1 highaltitude reconnaissance jet derived in turn from the famed Lockheed U-2 spy planes, left the NASA Ames Research Center in California on 8 January on a flight to Darwin via Hawaii and Guam. Its $1400-\mathrm{kg}$ package of 16 instruments in the fuselage and two under-wing pods is the heaviest science payload the aircraft has ever carried.

Waiting at an Australian Air Force Base near Darwin to begin a month-long assault on large tropical storm buildups is a multinational research team for STEP. The project, five years in the making, is coordinated with two other studies, the Australian Monsoon Experiment (AMEX) and the Equatorial Mesoscale Experiment (EMEX). Participating agencies include NASA, the US National Oceanic and Atmospheric Administration (NOAA), the Australian Bureau of Meteorology, and several universitybased groups. In addition, the crew of a research vessel from the People's Republic of China will help, launching radiosonde balloons and carrying a USsupplied weather radar to track storm systems for the combined effort.

While the sailplane-like ER-2 flies above, and into, the anvil-shaped tops of massive storms at 60,000 feet and above, other American and Australian aircraft will inspect lower altitudes. The measurements from the Chinese ship will augment a network of a dozen radiosonde and six radar sites along northern Australia.

NASA aims to sort out the precise nature of an atmospheric transport system known as the Walker Circulation, a convective cell with predominantly east-west orientation. STEP will examine the western end of the Walker Circulation as it gathers moist, warm low-level air flowing from near the coast of Mexico, lifting it up over the Western Pacific to feed dry, cold winds blowing back to the east.

Conventional wisdom has it that tropical thunderstorms flatten out at 50,000 feet or so. "We've seen them to 60,000 feet here, and radar suggests they go even higher," according to NASA meteorologist, Edwin Danielsen.

It is an issue only direct measurement can settle. The ER-2's pilots will fly above and into the cloud sheets swept outward of thunderstorm tops, giving them their characteristic anvil shapes as stormclouds overshoot points of equilibrium, flatten out, and extend downwind. The highaltitude cloud decks, rapidly losing heat to the dark sky above, and absorbing radiant heat from the sea, should become vigorously convective. As the NASA team sees it, they will become heat engines, pumping tropospheric air up, while condensing water into ice that falls back down.

Ozone, photochemical nitrogen compounds, and cosmogenic isotopes such as beryllium- 7 and phosphorus -32 characteristic of the upper stratosphere, will be compared to aerosols, water vapour and water ice, carbon monoxide and radon daughters swept up in the tropopause. Temperature, wind speeds and pressure will all be carefully charted.

The project offers another big bonus Pending approval of Chilean authorities to use an airfield at the southern tip of South America, NASA and NOAA officials plan to send the plane over Antarctica in August and September. This is when the height of the recently reported annual south polar ozone depletion is expected to occur (Nature 300, 686; 1982). The Antarctic mission may uncover the role of man-made pollutants, delivered to the upper atmosphere through such mechanisms as the western Pacific stratospheric fountain, in piercing the hole in the ozone.

\section{Italy's nuclear forum is postponed}

\section{London}

A CONFERENCE billed to "decide the future" of nuclear power in Italy has been postponed, throwing the Italian nuclear lobby into confusion.

Prime Minister Bettino Craxi's Socialist-Christian Democrat coalition government has equivocated on nuclear energy in public, but privately is said to back the country's recent "energy plan" to build two or three pressurized-water reactors (PWRs, Italy's first). The conference plan was supposed to be the political solution. To help satisfy public opinion, the government was (and in principle still is) to hold an open, three-day parliamentary conference covering all aspects of nuclear power, particularly safety. This was due to take place next week; but it always seemed to be a dangerous balancing act destined to receive a great deal of media attention, but with no clear powers of decision, so the postponement is perhaps unsurprising.

The Chernobyl accident last year caused an uproar in Italy. Although the country was only slightly exposed to fallout from the explosion of the Ukrainian reactor, Italian politicians (who may soon face an election, were careful to listen to public complaints, and one after another of Italy's many political parties pledged itself against nuclear power. By late last year there was a political lobby large enough to pose a serious threat to the country's fledgling nuclear power programme.

Not only are the plans uncertain for new PWRs in Italy, but also for existing reactors and those under construction. Only four per cent of Italian electric power is nuclear-generated. (Italy is dependent upon foreign imports for some 80 per cent of its energy, making it one of the highest import dependences in Europe.) Two boiling-water reactors are in an advanced state of construction at Montalto di Castro (between Rome and Pisa), and work has begun on three PWRs sited east of Turin in the Piedmont, east of Milan in Lombardy, and south of Rome. Allowing for the decommissioning of older reactors, this would take Italy to around $25,000 \mathrm{mil}$ lion $\mathrm{kWh}$ per year of nuclear generating capacity by 1995 , which would still amount to only 10 per cent of the country's requirements for electricity by that date, according to the Italian nuclear and alternative energy agency ENEA. The strategy, according to the president of ENEA, Professor Umberto Colombo, is to "hold the position" until renewable and fusion energy becomes available, although, he 
admits, that could be "forty to fifty years away".

Safety will be the main issue at the conference, but the Italian commitment to the fast breeder reactor will also be in question. Italy owns a one-third share in Europe's - and the free world's largest such reactor, the 1,300 MW Superphénix (at Creys-Malville on the French Rhône river), and is also party to a Europe-wide agreement on fast reactor research and development. But the Italian Communist Party (a party of Eurocommunists who distance themselves from Moscow, unlike their French equivalents) has set itself firmly against fast reactors. The Communists are by far the strongest of Italy's left-wing groups, and Colombo is "sorry" that Italian withdrawal from fast-breeder research now seems "likely", although continued participation in Superphénix is ensured (for the electricity it provides Italy). The most immediate impact of withdrawal from research would be the end of the so-called PEC $120 \mathrm{MW}$ (thermal power) experimental fast breeder, designed to study fuel safety, which is now 70 per cent complete on a site midway between Bologna and Florence.

Craxi's conference to "decide" on even this small amount of nuclear power and nuclear research has already begun in one

sense: the industry ministry in Rome has sent questionnaires to 150 environmental groups, nuclear power and other institutions, asking for their forecasts of future electricity demand and supply in Italy, their estimates of environmental damage and risk, and for proposals for an institutional framework for managing Italian energy and any accidents that might arise.

The conference proper will consist of analysis of the replies, reports by invited experts from Italy and the rest of the world and most critically a closing assessment by the government.

Then, an interparliamentary commission will attempt to reach conclusions, but as Colombo predicts, the short conference is likely to leave a very divided field. An assessment of likely votes is as likely to sway politicians as an assessment of technical arguments, and for the Italian nuclear power lobby a public "bella figura" at the conference must be essential.

Meanwhile, however, the spring date approaches when Craxi (a socialist) has promised to hand over the premiership to his Christian Democrat colleagues. $\mathrm{He}$ has refused to do this once before, and many think the same thing may happen again, this time precipitating a general election. That could mean Italy's energy future being decided in the white heat of Italian politics.

Robert Walgate

\section{Landsat remote sensing project short of funds for satellites}

\section{Washington}

As a result of a delay in 1987 budget negotiations between Congress and the National Oceanic and Atmospheric Administration (NOAA), work on the two newest Land Remote Sensing Satellites (Landsats 6 and 7) has ground to a halt.

The Earth Observation Satellite Company EOSAT, dependent upon a NOAA subsidy to construct the new satellites, has been forced to terminate Landsat development subcontracts. These contracts were held by the Santa Barbara Research Center of Hughes Aircraft Company and General Electric's RCA Astro-Space Division, among others. Termination of the subcontracts will mean layoffs of up to approximately 200 scientists and technicians for each major contractor, and the loss of 17 marketing support personnel for EOSAT. Although the two currently operating Landsats 4 and 5 will not be immediately affected, a continued lack of funds could drive EOSAT into a worse predicament.

For the past five years, NOAA has been a favourite target of Reagan administration budget cuts, struggling each year to get funding. EOSAT has been prone to the vagaries of the forces influencing the NOAA budget since it was formed to commercialize the Landsats. In 1985, when EOSAT took over the Landsats, Congress decided that EOSAT would receive $\$ 250$ million in start-up funds, to carry EOSAT through the deployment of Landsats 6 and 7. So far, each year EOSAT's subsidy has been deleted from the NOAA budget by the Office of Management and Budget (OMB), only to be put back in by Congress.

For 1987 , EOSAT was scheduled to receive $\$ 87$ million, but $\mathrm{OMB}$ did not approve NOAA's budget. Congress then approved the appropriation of $\$ 27.5 \mathrm{mil}$ lion of new money for EOSAT, but demanded that NOAA provide a detailed plan for the use of the funds. The request for a new plan was prompted by delays in the Shuttle programme since the Challenger accident left the Landsats with no launch vehicle.

The current, unapproved NOAA plan calls for a $\$ 209.2$ million total subsidy, down from the original $\$ 250$ million, for the development of only one satellite instead of two. Launch is proposed for 1989 using a Titan 2 missile. This means a budget in 1987 of $\$ 62.5$ million. EOSAT says it requires a minimum of $\$ 69.5$ millon in 1987, and is still pushing for plans for two new satellites.

\section{NASA mosquito watch threatened}

\section{Washington}

Predicting malaria outbreaks from space may be possible using a model being developed by the National Aeronautics and Space Administration (NASA). The model will use remote-sensing images taken by Land Remote Sensing Satellites (Landsats) of malaria-prone regions to forecast when and where outbreaks are likely to occur. But the budgetary problems that have recently befallen the Earth Observation Satellite company (EOSAT), Landsat's owner, may mean that projects like the malaria watch will have trouble getting off the ground.

If money problems can be solved, the first phase in the development of the malaria model will take place this summer in the rice fields of Northern California. A local species of mosquito is closely related to the ones that spread malaria elsewhere, although California's control measures have rendered the state virtually free of the disease. According to project chief Paul Sebesta, researchers at the NASA Ames Research Center will be collecting "ground truth" data to work out the relationship between the satellite images of ground reflectance patterns and the variables that influence the proliferation of malariabearing mosquitoes. Such ground variables include surface water distribution, rainfall patterns, drainage, vegetation type and temperature. Once these relationships are established, it will be possible to predict both the extent of the mosquito population and how long it will thrive.

The second field trial of the new technique will begin in 1988 in the southwestern oceanic plain of Mexico, near Tapachula, a site with a large malarial mosquito population. The Mexican location was selected during a workshop between NASA scientists and world health officials held early last year at the Uniformed Services Medical Center in Bethesda, Maryland. Criteria for choosing a site were that it should have only one species of mosquito serving as the malaria vector, be politically stable and easily accessible. Costa Rica, Turkey, Pakistan and China were also considered, and they are likely to top the list for future trials. If successful, the model will be turned over to national and international malaria control authorities. Carol Ezzell

Congress, EOSAT, and NOAA are still trying to reach a compromise. Once an agreement has been settled, however, EOSAT will have to renegotiate the contracts with its subcontractors, a task that could set the project for the new Landsats back by nearly two months. Meanwhile, EOSAT, Landsat and the fate of any projects dependent upon Landsat data are caught in budgetary limbo. Carol Ezzell 